\title{
QUARUP: \\ TRANSFORMAÇÕES DO RITUAL E DA POLÍTICA NO ALTO XINGU*
}

Antonio Guerreiro

\section{Introdução}

Este artigo trata de transformações do ritual e da política entre os povos do complexo multiétnico e multilíngue do Alto Xingu, a partir de uma investigação sobre como não índios, dinheiro e mercadorias têm sido incorporados ao patrocínio de rituais mortuários. Em sua maior parte, ele se baseia na pesquisa de campo que venho desenvolvendo com os Kalapalo (falantes de língua karib), mas também utilizo informações e observações provenientes de outros grupos da região. Partindo da descrição de alguns rituais realizados nos últimos anos, discuto como sua objetivação enquanto "cultura" para os brancos ${ }^{1}$ põe em movimento processos políticos de escala local, regional e nacional. Minha intenção é compreender como os rituais se tornaram uma dobradiça entre o mundo dos brancos e a política ritual indígena, e como isso pode afetar as formas xinguanas de produção de pessoas e coletivos. Além disso, também espero esclarecer alguns aspectos das ideias xinguanas sobre a chefia e a noção de "dono".

Nos meses de agosto e setembro, tornou-se comum ver circulando pelas redes sociais convites para os rituais mortuários realizados pelos povos do Alto Xingu (o famoso Quarup, no qual chefes e outras pessoas são homenageados sob a forma de efígies de madeira). Alguns têm se tornado grandes eventos, com a ampla participação de políticos e personalidades públicas, mobilizando muito dinheiro, setores do Estado, pautas nacionais e projetos de "etnodesenvolvimento". Para os povos da região, de um modo geral, trata-se de aproveitar um momento da produção de sua socialidade para se relacionarem, de forma intencional, coletiva e (mais ou menos) controlada, com os brancos. Os xinguanos sabem bem o poder de atração que têm seus grandes rituais. Foi a participação em um sistema articulado por tais eventos coletivos que permitiu a assimilação de uma diversidade de povos no decorrer de seus mil anos de história (Heckenberger, Fausto, 
Franchetto et al. 2003; Heckenberger, Russel, Fausto et al. 2008) e, ao que parece, também tem proporcionado algumas formas de incorporação dos não índios ao complexo regional. Contudo, isto não se passa sem complicações.

Certa vez, em 2009, conversando com um jovem matipu sobre a grande quantidade de festas ${ }^{2}$ (rituais mortuários) que vinham sendo feitas e que ainda seriam realizadas no ano seguinte, ele me revelou uma preocupação. Comentávamos como a quantidade de festas vinha aumentando, e como hoje praticamente todo parente de chefe recebe uma homenagem. Esta seria uma situação diferente do passado, quando apenas grandes chefes, que haviam se tornado famosos (tuhutinhü, ${ }^{3}$ " conhecidos", ou tikaginhü, "comentados") recebiam homenagens póstumas, que às vezes demoravam anos para acontecer. Com um tom receoso, ele me disse: "Você sabe qual é o nosso verdadeiro problema? O problema do Xingu é o feitiço. Os donos do feitiço estão matando nossas lideranças, para que os kagaiha kuẽgü ${ }^{4}$ ["Hiper Brancos", isto é, brancos não brasileiros] tragam dólares". Na ocasião, o rapaz estava preocupado com a morte consecutiva de vários chefes importantes e seus primogênitos (seus sucessores ideais), eventos que estavam na origem dos rituais mortuários de que falávamos. Sua constatação era de que a morte de tantas pessoas de prestígio parecia ser um meio encontrado por feiticeiros para captar dinheiro com o etnoturismo internacional - algo condizente com a imagem que se faz dos feiticeiros enquanto pessoas avarentas, capazes de prejudicar até seus parentes mais próximos em proveito próprio.

Esse jovem matipu nos apresenta uma teoria que põe no mesmo plano a feitiçaria, o complexo de rituais regionais ligados ao ciclo de vida dos chefes e a forma como estes eventos têm incorporado a presença de não índios (nesse caso, estrangeiros) e coisas do mundo não indígena (na fala dele, dinheiro especificamente dólares, ou tinhegu kuẽgü, "dinheiro grande, de longe, poderoso"). Mas seria uma teoria sobre o quê, exatamente? Minha hipótese é de que se trata de uma teoria política da "cultura", ou melhor, sobre o que algumas pessoas - índios e não índios - têm chamado de cultura em contextos nos quais esse conceito é tomado como o foco de suas interações.

No Alto Xingu, os rituais - assim como seus objetos, matérias-primas, cantos, grafismos, técnicas corporais etc. - são aquilo que mais frequentemente se traduz como "cultura". São talvez a parte mais importante do que os karib chamam de tisügühütu, "nosso jeito de ser". Mas os sentidos mobilizados pelos xinguanos nessa tradução não necessariamente coincidem com o que pensam sujeitos e instituições que pautam suas relações com eles em alguma ideia de "cultura", e de como ela pode ser tornada visível. Segundo Carneiro da Cunha, a "cultura" com aspas pode ser vista como uma mobilização reflexiva do conceito de cultura em contextos de relações 
interétnicas (Carneiro da Cunha 2009), ou seja, uma objetivação, voltada para outrem, de um universo simbólico. Isto coloca uma questão: o que é uma objetivação no mundo ameríndio, isto é, o que, no mundo ameríndio, pode ganhar visibilidade e se tornar meio de uma relação?

Hugh-Jones observa que a troca de dádivas, quando comparada à guerra e ao canibalismo, ocupa um lugar etnográfico secundário na etnologia americanista, a não ser quando tratada da perspectiva da teoria da aliança (Hugh-Jones 2013). Alguns autores argumentam que a troca de dons na América do Sul indígena seria pouco desenvolvida em função da inexistência de algum "princípio de substituição" (Descola 2001) de pessoas por coisas, fazendo com que a dádiva se constituísse na circulação de partes de pessoas ipsis literis: corpos de cativos, cabeças, nomes próprios etc. (Descola 2001; Kelly 2001). Contudo, Hugh-Jones argumenta que a troca de dons seria um aspecto relevante dos "sistemas regionais" ameríndios, que teriam como característica a ampliação, para muito além do grupo local, de formas de relacionamento que em boa parte da Amazônia seriam peculiares à socialidade intra-aldeã (Hugh-Jones 2013:357). A recorrência de tensões em torno da categoria "dono" quando se trata de transformar o ritual em "cultura" (algo que ao menos os não índios veem como um objeto) sugere que as ideias xinguanas sobre a troca podem ser importantes para compreender o que está em jogo.

Estaríamos diante de universos sociais marcados não pelo regime da mercadoria (em que pessoas e coisas assumem a forma social de coisas), mas pelo regime da dádiva, no qual pessoas e coisas assumem a forma social de pessoas (Gregory 1982). No regime do dom, tudo que é objetificado carrega propriedades e capacidades do doador (entendido ele mesmo como o produto transitório de uma relação), e tem a capacidade de produzir pessoas e relações. Conforme Strathern (1988), a objetificação em economias do dom deve ser vista como um momento de processos de personificação.

Esta afirmação - que faz da circulação da "cultura", enquanto objeto, um momento de processos de produção de pessoas e relações sociais aponta para as raízes de alguns mal-entendidos recorrentes entre xinguanos e não índios. Ao discutir a realização de rituais de máscaras visando à sua posterior comercialização pelos Wauja (arawak xinguanos), Barcelos Neto mostra como certos itens de cultura material teriam sua comercialização impedida por não pertencerem aos Wauja, mas aos espíritos para os quais foram produzidos. Sua venda seria um desrespeito para com estes seres, pois consistiria em tratar como objetos artefatos que, na realidade, são partes de sujeitos que podem ser reanimados de tempos em tempos nos rituais (Barcelos Neto 2006:92). 
Objetos da cultura material xinguana também podem manter suas capacidades agentivas mesmo depois de terem sido vendidos. Foi este o caso das máscaras Atujuwá produzidas pelos Wauja para serem utilizadas em um espetáculo no Festival de Radio France et Montpellier, e posteriormente vendidas ao Musée du Quai Branly, em Paris. Como todo objeto ritual que personifica um espírito, as máscaras devem ser bem alimentadas para que substituam sua agência patogênica por uma relação de proteção ao seu dono. Durante sua estadia em Montpellier, os Wauja ficaram incomodados com o modo como foram recepcionados: a água que havia sido comprada pela produção lhes parecia salgada, não haviam recebido vales para o café da manhã, e tampouco lhes haviam sido comprados cigarros, sobretudo para os xamãs. O que os patrocinadores do espetáculo consideravam um luxo, os Wauja consideravam uma necessidade, pois os patrocinadores deveriam, por meio da oferta abundante de comida, bebida e tabaco, acalmar os espíritos das máscaras Atujuwá para evitar que eles os atacassem e os deixassem doentes (Fiorini \& Ball 2006).

Incomodados com o tratamento recebido, os Wauja deixaram nas máscaras vendidas ao Musée du Quai Branly as mandíbulas de piranha com as quais confeccionam as bocas desses objetos-espíritos, para que elas mantivessem sua ferocidade diante de seus novos donos (Barcelos Neto, comunicação pessoal, 2014). Fiorini e Ball argumentam que, apesar da performance em Montpellier não ter sido exatamente $o$ ritual, ela não deixaria de ser um ritual, na medida em que os Wauja mobilizaram aspectos das relações de reciprocidade envolvendo espíritos, patrocinadores e executantes, característicos de seus rituais, a fim de tentarem controlar suas relações com uma categoria peculiar de Outros: os franceses (Fiorini \& Ball 2006:97).

Trabalhos como estes focalizam o "comércio da cultura" xinguana principalmente a partir da circulação de elementos de cultura material, ou seja, de coisas que em seus contextos convencionais de produção e uso assumem a forma de objetos. Os rituais de homenagem póstuma parecem colocar questões um pouco diferentes. Em primeiro lugar, eles não são tão "destacáveis" quanto objetos de cultura material e, assim, quem tende a circular com sua comercialização são seus "consumidores" (os brancos e, claro, os xinguanos de outras aldeias). Além disso, se os rituais de máscaras/ espíritos lidam com a ambiguidade de objetos que podem aparecer como sujeitos, ou vice-versa, os ritos de chefia parecem colocar em questão as posições de sujeito ou objeto dos próprios grupos xinguanos. Por fim, se nos casos descritos acima os espíritos aparecem como foco de desentendimentos ontológicos entre brancos e xinguanos, nos rituais mortuários entram em 
disputa elementos da política regional - como as relações hierárquicas que caracterizam a chefia - e a tensão entre hierarquia e simetria que perpassa as relações entre grupos locais.

Discutindo o "comércio de culturas" na Melanésia, Simon Harrison argumenta que rituais podem ser tratados simultaneamente como conhecimentos e riquezas, propriedades valiosas que podem ser adquiridas por outros grupos que desejem realizá-los. Rituais poderiam ser vistos como objetos de valor que circulam segundo a mesma lógica com a qual riquezas materiais o fazem em complexos de trocas como o kula e o moka (Harrison 1993). Se rituais tidos como propriedades coletivas podem ser vistos como riquezas, a capacidade de as pessoas ocuparem posições específicas em suas performances também poderia ser vista como uma forma de "propriedade" (Harrison 1992), indicando diferenças nas relações de poder internas ao grupo. Assim como a capacidade de mobilizar riquezas materiais através de circuitos de trocas garante a um big man o fluxo de bens dos quais ele deve dispor para continuamente produzir sua posição, a posse de prerrogativas rituais também poderia implicar a produção de distinções sociais. Conforme Harrison, a ação ritual ocupa, no universo das ações, uma posição equivalente aos objetos de luxo em sistemas de trocas de dons competitivos: são formas de riquezas que podem ser transacionadas e, ao fazê-lo, provocam mudanças nas relações sociais (Harrison 1992:225).

Não há, no Alto Xingu, nada como a "venda" de rituais de um grupo a outro como na Melanésia, descrita por Harrison (apesar de conhecimentos especializados, como cantos, exigirem pagamentos para sua transmissão cf. De Vienne \& Allard 2005). Porém, quando os não índios entram em cena, emerge uma situação análoga, na qual rituais são transformados em objetos de transações que nem sempre têm os mesmos sentidos e propósitos para todos os envolvidos. Segundo Coelho de Souza, é preciso investigar "quais os efeitos que a 'objetivação da cultura' (a emergência da 'cultura' como fenômeno reflexivo, a objetivação de uma objetificação) poderiam ter sobre regimes de subjetivação que não dependem dessa primeira objetivação" (Coelho de Souza 2010:8). Que tipo de vínculo a ação ritual, objetivada como "cultura", é capaz de criar com agentes que não participam dela tradicionalmente? Como essas relações afetam as formas pelas quais a socialidade indígena é objetivada — seja como ritual para os vizinhos xinguanos, seja como "cultura" para os brancos - e que efeitos isto pode ter sobre os modos xinguanos de produção de pessoas e coletivos? Ainda, o que os eventuais desencontros em torno dos sentidos da "cultura" podem nos dizer sobre as concepções xinguanas da socialidade e suas transformações contemporâneas? 


\section{A inflação dos rituais mortuários e sua objetivação como "cultura"}

Dez povos falantes de línguas distintas vivem no complexo multiétnico e multilíngue do Alto Xingu, um sistema regional articulado por casamentos, comércio e rituais. Os Kalapalo, Kuikuro, Matipu e Nahukua pertencem à família karib; os Wauja, Mehináku e Yawalapíti, à família arawak; os Kamayurá e Aweti, ao tronco tupi; e os Trumai, que têm uma participação periférica no sistema, falam uma língua considerada isolada (Franchetto 2011).

Situado na região dos formadores do rio Xingu, no Brasil Central, este sistema social encontra-se na porção sul do Parque Indígena do Xingu (PIX). Segundo Heckenberger (2005), a ocupação indígena da área remonta aos séculos VI-IX d.C, e o sistema tal como ficou conhecido a partir dos primeiros relatos escritos sobre a região (Von den Steinen 1940,1942) parece ter se formado entre os séculos XVIII e XIX. Os rituais regionais são uma das mais importantes formas de socialidade que costuram este complexo, sendo considerados uma das principais marcas da condição de "gente xinguana", ou simplesmente "gente".

Estes rituais são como uma "língua franca" da região, que viabiliza interações entre povos que não necessariamente se compreendem linguisticamente (Bastos 1983), e podem ser divididos em duas grandes categorias: "festas para espíritos" e "festas para pessoas importantes" (Fausto 2007; Guerreiro 2012). As primeiras tendem a se restringir ao grupo local, ${ }_{1}^{5}$ estão ligadas a processos de adoecimento e cura, ao xamanismo, e variam razoavelmente de grupo para grupo (Barcelos Neto 2008; Franco Neto 2010). Já as festas para pessoas importantes são essencialmente regionais, exigem no mínimo a participação de três grupos ${ }^{6}$ e gravitam em torno do ciclo de vida dos chefes (anetü) e seus parentes (que chamo de "nobres" "). Estes eventos são o foco das relações pacíficas formalizadas entre os alto-xinguanos, e operam como momentos importantes de produção da socialidade. O ciclo de vida de qualquer mulher ou homem alto-xinguano é indissociável do ciclo de vida dos nobres, que criam, nos rituais regionais, as condições para que a produção de pessoas se complete e recomece.

De todos estes rituais, o Quarup ${ }^{8}$ (egitsü, em karib xinguano) foi e tem sido um dos mais importantes meios de consolidação do sistema interétnico pacifista da região, sobretudo após a aproximação forçada das aldeias no começo da década de 1960. Marcado como uma prerrogativa da nobreza (apesar de mortos comuns poderem ser lembrados ao lado de chefes), e tendo como ápice a ritualização da violência nos confrontos da luta esportiva da região, o Quarup é considerado um marco da diferenciação dos alto-xinguanos em relação a seus vizinhos belicosos e, junto com outros rituais 
regionais patrocinados pelos nobres, a condição para a reprodução desta distinção (Gregor 1990:113).

Desde a intensificação do contato com a sociedade brasileira, a partir de 1946, os rituais também se transformaram em uma espécie de língua franca entre os xinguanos e os caraíba (expressão pan-xinguana para "não indígena"). Os irmãos Villas Boas, chefes da expedição Roncador-Xingu e idealizadores do PIX, rapidamente perceberam como as relações pacíficas entre os grupos do Alto Xingu estavam ligadas à sua participação nos rituais. No intuito de consolidar o regime de paz que viabilizaria a criação do Parque (Bastos 1992), esses agentes estatais incentivaram a expansão do sistema ritual xinguano, sugerindo a inclusão de grupos que até então não faziam parte plenamente dele, e mesmo a eventual realização de rituais em um espaço imaginado pelos brancos como "neutro" (o Posto Leonardo Villas Boas, polo administrativo da região Sul do Parque e centro de atendimento à saúde indígena).

Povos belicosos, como os Kĩsêdjê ${ }^{9}$ e Ikpeng, passaram a ser convidados para algumas festas, na expectativa de que sua inclusão efetiva no circuito de hospitalidades rituais suprimisse a possibilidade de confrontos. Os Trumai, que antes do contato aparentemente só partilhavam o Jawari (hagaka, ritual de arremesso de dardos entre primos cruzados), durante certo tempo também passaram a frequentar o Quarup a pedido dos irmãos Villas Boas, e um chefe Trumai chegou a cantar no Quarup de um deles (Leonardo), realizado nos anos 1960. Segundo Barcelos Neto (comunicação pessoal, 2014), somente na década de 1970 os Wauja teriam participado pela primeira vez de um Jawari.

Nesse contexto, o ritual mortuário dos nobres começou a tomar proporções que talvez nunca tenha tido antes do contato. ${ }^{10}$ Quando as aldeias eram ainda mais distantes, a pax xinguana não garantia viagens livres de ataques inimigos, o deslocamento era complicado, e um Quarup dificilmente reunia mais do que duas ou três aldeias convidadas (ligadas por laços mais próximos de consanguinidade e afinidade). Com a criação do Parque em 1961, a aproximação das aldeias nos anos subsequentes e a ampliação do uso de barcos a motor, a situação mudou muito, e convidar todos os grupos não só se tornou possível como indispensável. Além disso, o advento de ferramentas de metal, anzóis e redes de pesca industrializadas permitiu a obtenção de alimento em proporções inéditas para os grupos convidados.

Estes eventos também se tornaram ocasiões para receber jornalistas, políticos, fotógrafos, pesquisadores e personalidades variadas, que passaram a divulgar uma visão do Parque intimamente ligada à imagem pacifista dos povos do Alto Xingu (deixando de lado a imagem dos povos mais "guerreiros" do PIX, inclusive amenizando a relevância da violência desencadeada 
entre os próprios alto-xinguanos pelas acusações de feitiçaria). Os rituais regionais começaram a funcionar como um meio de atrair a atenção da sociedade nacional e de personalidades internacionais para o Parque e seus habitantes, que passaram por um processo pelo qual estes últimos, com sua refinada estética ritual e o pacifismo correlato, foram transformados no "cartão-postal" da indianidade brasileira e em uma espécie de vitrine para um novo modelo de indigenismo. ${ }^{11}$

Os não índios foram rapidamente incorporados à lógica dos rituais da chefia, e personagens importantes para a história do Xingu receberam, após a sua morte, a mesma homenagem que a nobreza xinguana (como foram os casos de Leonardo, Cláudio e Orlando Villas Boas, do médico Noel Nutels, do brigadeiro Faria Lima, e do indigenista Apoena Meireles). Esses eventos também apresentaram outra possibilidade, que vem sendo fartamente explorada: a de continuamente atrair atenção para os povos do Parque e criar novas alianças com os brancos.

O caso do Quarup realizado para o jornalista e empresário Roberto Marinho (fundador da Rede Globo de telecomunicações) pelos Kamayurá em conjunto com os Yawalapíti, em 2004, é um exemplo. Segundo Sapaim, um importante xamã kamayurá, os espíritos teriam lhe pedido em sonho que fizessem uma homenagem a Roberto Marinho (falecido em 2003), afirmando que a Rede Globo havia sido fundamental para que os índios do Xingu pudessem ser nacional e internacionalmente conhecidos (Funai 2004). Foi uma ocasião marcada pela presença de inúmeras autoridades, dentre elas o então ministro da Justiça Márcio Thomaz Bastos, que firmou compromissos verbais de cooperação entre o governo Lula e os povos do Alto Xingu, amplamente divulgados pela mídia (cf., por exemplo, Carvalho 2004). Recentemente, em agosto de 2012, os Yawalapíti também homenagearam o antropólogo Darcy Ribeiro, ${ }^{12}$ que redigiu o projeto do Parque. Fruto de um acordo com a Fundação Darcy Ribeiro, os Yawalapíti viram na ocasião uma oportunidade para obter recursos para a aldeia e chamar a atenção de políticos e da grande mídia para questões indígenas em pauta, como a construção da hidrelétrica de Belo Monte e projetos de lei que restringem os direitos indígenas.

O que era para cada povo egitsü (karib), kaumai (wauja), itsaxi (yawalapíti), torïp (kamayurá) se tornou, paulatinamente, Quarup: uma dobradiça entre a política ritual indígena e o mundo dos brancos. Com uma nova proporção e com uma crescente demanda por convidados não indígenas, o ritual parece flertar com uma espécie de "processo inflacionário". A metáfora econômica é certamente imperfeita, mas permite destacar dois movimentos concomitantes. De um lado, há uma intensificação da vida ritual com o au- 
mento da quantidade de festas. De outro, estas parecem sofrer uma relativa "desvalorização", relacionada por muitos ao fato de as homenagens não se restringirem mais a grandes chefes, e serem às vezes realizadas "de qualquer jeito" em aldeias menores ou sem os devidos cuidados com objetos e ações rituais (os Kalapalo contam que as efígies deveriam ser preparadas secretamente no interior da casa dos homens, mas esta prática caiu em desuso para que o processo pudesse ser filmado). Seu patrocínio também está se tornando cada vez mais caro: cresce a demanda dos convidados indígenas por algodão para os enfeites e gasolina para o transporte; os objetos especializados que os chefes devem trocar entre si estão perdendo a equivalência de valor; e os serviços funerários demandam pagamentos cada vez mais substanciais, às vezes sob a forma de dinheiro ou mercadorias. ${ }^{13}$

A seguir discutirei alguns episódios ligados a rituais mortuários específicos realizados pelos Kalapalo ou outros grupos xinguanos. Optei por discutir casos pontuais, ao invés de investir na descrição de um único evento, pelo fato de cada situação levantar problemas distintos na objetivação dos rituais como "cultura". Como veremos, em todas as situações apresentadas, a categoria "dono" (oto) ocupa um lugar central, mas cada uma revela como facetas distintas dessa posição e das relações que ela implica podem gerar mal-entendidos sobre o que constitui a "cultura", como ela pode se dar a ver, e como ela pode ser feita circular.

\section{Fama e grandeza: homenageando autoridades}

Os Kalapalo costumam chamar políticos e funcionários importantes dos governos municipal, estadual ou federal de autoridades. Os que ocupam posições de destaque, como prefeitos, o governador do Mato Grosso, a presidente da República e o presidente da Funai, ao lado de outras autoridades são às vezes chamados de caciques, ou "caciques brancos". Assim como os chefes tradicionais se amparam em outros chefes, esses caciques têm nas autoridades seus "ajudantes" (itaginhokongo, "com quem se conversa"), parceiros de liderança, e também têm seus "seguidores" (isandagü) e "funcionários" (ngengoku). Em linhas gerais, a política não indígena é lida pelos Kalapalo como algo análogo à sua própria política.

Há, porém, algumas diferenças que os Kalapalo fazem questão de ressaltar. Ao contrário da chefia tradicional, que seria "eterna" (tüteminhü), os brancos insistem em substituir seus chefes o tempo todo. Outra peculiaridade seria a sua avareza e seu apreço pela mentira. Enquanto os chefes xinguanos são educados desde a infância para cultivar a generosidade e 
o que se chama de "fala verdadeira" (akihekugene), os chefes brancos se sustentariam propagando uma falsa generosidade.

Ainda assim, como já comentei, não é incomum que brancos aliados ou com os quais se deseja produzir alianças sejam colocados em posições equivalentes às dos chefes nos rituais mortuários, como homenageados e/ ou donos-patrocinadores. Esta relação dos não índios com o grupo pode ser uma fonte de complicações, pois a política local é largamente marcada por disputas entre os chefes que, quando patrocinam rituais regionais, almejam realizar eventos que lhes rendam fama e grandeza - conceitos centrais para a chefia xinguana.

Há alguns anos, os Kalapalo cogitaram a possibilidade de realizar um Quarup em homenagem ao falecido presidente Tancredo Neves. Pelo que se soube, parentes do ex-presidente teriam pedido esta homenagem aos Kalapalo há algum tempo, em 2006 (ano de eleições presidenciais). Naquele ano, aconteceu um Quarup na aldeia Aiha (sua maior e mais importante aldeia), mas por falta de tempo e pelo fato de uma emissora de TV britânica estar filmando um reality show durante o evento, a homenagem não aconteceu. Em 2007, os Kalapalo não patrocinaram nenhum Quarup e, em 2008, os planos foram novamente frustrados por não terem conseguido entrar em acordo com os interessados sobre os pagamentos e a aquisição de recursos para a festa.

No final daquele ano, parecia tudo arranjado para que a homenagem finalmente acontecesse em 2009, durante um Quarup que seria realizado em outra aldeia kalapalo em homenagem ao falecido neto de um de seus chefes. O principal responsável por mediar as negociações com a família do homenageado dizia estar interessado em obter ajuda de políticos influentes para o processo de demarcação do território de um antigo grupo karib próximo dos Kalapalo, os Angaguhütü (os "Naruvôtu" ou "Anaravuti" da literatura). Havia muitos rumores sobre a festa, e os Kalapalo estavam visivelmente entusiasmados com a quantidade de pessoas importantes que participariam do evento, com o dinheiro e os presentes que receberiam, e com a fama que eles e o dono do ritual ganhariam. Segundo um kalapalo que comentou o assunto:

Os Kalapalo vão ficar muito mais famosos do que os Yawalapíti, vai ter muito mais autoridades que no Quarup do Orlando Villas Boas [realizado por aquele povo em 2003]. Orlando era um "cacique pequeno", este que nós vamos homenagear é que era um cacique de verdade, porque era um presidente do Brasil!

Preocupações semelhantes com os possíveis efeitos de uma festa sobre seus patrocinadores surgiram em um Jawari (como já mencionei, um ritual 
de arremesso de dardos entre primos cruzados) que os Kalapalo organizaram para Orlando Villas Boas em 2011. Ouvi falar desse evento desde meados de 2010 e, naquele ano, seu idealizador me disse que teve essa ideia "para conseguir algumas coisas pra comunidade" (principalmente um barco e um motor de popa, que teriam sido solicitados à família do homenageado). Passado algum tempo, ele me ligou para fazer o convite formal para o evento e, pelo que ele dizia, a festa teria uma proporção inédita:

Aqui vai ficar muito cheio, não vai ter lugar pra todo mundo direito, por isso você tem que decidir logo se vem ou não. Eu vou enviar convidadores [mensageiros rituais] pra todas as aldeias do Xingu, não só do Alto, mas vou convidar Ikpeng, Suyá, Kayabi, Juruna, e até os Kayapó! Virão o presidente da Funai, a família do Orlando, todos os prefeitos, fotógrafos, jornalistas, muita gente!

Espantado com a proporção que a festa teria (além dos povos do médio e do baixo Xingu não participarem das festas do Alto, a intenção de enviar mensageiros rituais me parecia algo excepcional), exclamei ao telefone: "Nossa, a festa será enorme!", ao que ele replicou: "A festa vai ser muito grande, e eu também vou ficar grande. Eu vou ficar famoso, todo mundo vai saber meu nome no Xingu, no Brasil e no mundo!".

Fama e grandeza são elementos centrais da política alto-xinguana. Um chefe é considerado "grande" quando é amplamente visto como bom e generoso por "seu pessoal", e fica ainda "maior" quando seu nome se torna famoso, conhecido entre estrangeiros (índios e brancos), em função de sua participação em rituais. Quanto mais um chefe ocupa a posição de "coordenador" (ugihongo, "que vai sobre o banco"; pessoa responsável por conduzir seu grupo a um ritual em outra aldeia) ou dono (oto) de rituais, mais ele é visto e comentado pelos estrangeiros. Diz-se que seu nome "fica sendo falado quando ele está longe", e que se comenta sobre sua índole, suas qualidades como lutador, e sobre suas relações de parentesco.

Homenagear um grande chefe em um Quarup é um elemento importante do processo de produção dos chefes-patrocinadores vivos. Os donos de um ritual são aqueles, entre os parentes masculinos mais próximos do morto, responsáveis por reunir e redistribuir todo o alimento necessário para cada fase do ritual, viabilizar o transporte dos convidados, fornecer enfeites para os cantores e pagar tarefas específicas, como o banho e a pintura que recebem para "tirar a tristeza". Estes patrocinadores são tidos como "cópias" imperfeitas, ou "imagens/sombras", dos chefes mortos, os quais substituem (Guerreiro 2011, 2012). A produção de uma efígie mortuária completa um processo de aproximação dos chefes ao ideal da pessoa xinguana, e também 
faz avançar esse processo entre os donos do ritual, de modo que a fama e a grandeza de um homenageado morto podem ter efeitos sobre a fama e a grandeza de seus parentes vivos. As falas acima sobre a fama que os Kalapalo ganhariam coletivamente com a possível homenagem ao falecido presidente, ou sobre como o idealizador do Jawari para Orlando Villas Boas ficaria grande e famoso, sugerem que mesmo agentes não indígenas trazidos para a performance ritual podem ser englobados por sua lógica: homenagear uma grande autoridade pode tornar seus patrocinadores maiores e mais famosos. Porém, justamente por sua externalidade, essa incorporação se torna objeto de desentendimentos.

O Quarup de 2009 aconteceu, mas sem a homenagem ao falecido presidente, pois a entrada de não índios no Xingu havia sido vetada para evitar uma possível epidemia de gripe H1N1. Contudo, a possibilidade de que a homenagem acontecesse fez com que a organização deste ritual se tornasse objeto de disputas entre três aldeias. Na época, a segunda maior aldeia kalapalo contava com três chefes importantes, e seu "primeiro cacique" (forma pela qual os Kalapalo se referem ao chefe principal de uma aldeia), que ocupava também a posição de "dono dos brancos" (kagaiha oto, o responsável por intermediar o contato com os brancos em geral), não residia em tempo integral na aldeia.

Nesse contexto, seu irmão mais novo, que se tornaria dono do Quarup de 2009, passou a ocupar seu lugar, e o fato de ele fazer questão de realizar a festa em sua aldeia foi um ponto importante de discussão. A maioria dos Quarup kalapalo acontece em Aiha, considerada a "capital kalapalo" — iho, "esteio", das demais. Uma aldeia-esteio é um ponto de referência identitário e ritual. Pode ser o grupo local de onde se originaram aldeias menores, ou o principal centro de atividades rituais de um conjunto de aldeias historicamente relacionadas (chamadas de "galhos", îkungu, quanto ao seu esteio). Aldeias-iho podem ser chamadas de "praça" no que concerne a outras, como se conjuntos multicomunitários pudessem sem tratados como aldeias em escala regional, e é dessas aldeias que derivam os nomes usados por diferentes grupos locais como etnônimos. Elas são análogas aos chefes de um grupo local, também considerados iho, esteio, de seus moradores.

Até então, poucos Quarup kalapalo haviam ocorrido fora de Aiha (o primeiro em 1999). É muito importante para um grupo alto-xinguano ter seus nobres enterrados e homenageados em sua própria aldeia, pois além do patrocínio da festa ser parte da produção dos parentes do morto como seus substitutos, isto desempenha um papel na produção da memória sobre um lugar e contribui para sua capacidade de produzir pessoas de forma autônoma (isto é, sem precisar realizar rituais em outras aldeias). ${ }^{14}$ 
Os moradores de Aiha estavam inconformados com a realização de uma festa dessa magnitude em uma aldeia que consideram "periférica". Promovendo um Quarup de forma autônoma, o chefe em ascensão não só dava um passo importante para legitimar sua posição, como afirmava a autonomia ritual de sua aldeia. Ela deixaria de ser um "galho" (îkungu) de Aiha, e se tornaria outro esteio em potencial. Ainda que em certa medida toda aldeia seja autônoma ou se queira como tal, as relações rituais evidenciam tendências à hierarquização das relações regionais, e o atual contexto kalapalo mostra como um sistema de aldeias "satélites" é latente, uma situação possivelmente mais comum no passado. ${ }^{15}$

Em 2011, também houve tensão em torno da realização de um Quarup em uma pequena aldeia. O pai do chefe desta aldeia, um homem jagamü (nahukua) já muito idoso, falecera no começo do ano. Ele não era chefe, mas foi casado com uma importante chefe mulher (itankgo) kalapalo. Uma mulher me contou que seu corpo havia sido levado por seu filho para ser enterrado em uma pequena aldeia, mas onde já havia se formado uma praça, e que ele havia anunciado que faria um Quarup lá para seu pai em 2012. "E você vai?", perguntei ao pressentir que havia algo estranho em seu tom de voz. "Não, por que eu iria? Lá não é uma aldeia de verdade, e ele não era chefe. Seu filho está fazendo isso pros brancos, só pra conseguir dinheiro". Quando toquei no assunto com outras pessoas, muitos manifestaram a mesma opinião, de que seria um Quarup "de mentira" para atrair brancos e conseguir dinheiro, e alguns repetiram a ideia de que não se poderia fazer um Quarup naquela aldeia, já que ela não era uma "aldeia de verdade".

Essas situações mostram que o local de realização de um ritual e os aliados não índios que o acompanham podem se tornar objetos de disputa, envolvendo o faccionalismo entre os chefes, o controle de aliados e seus recursos, e a assimetria regional entre as aldeias. No caso do Quarup para o falecido presidente, as possibilidades de aliança com autoridades e seus benefícios potenciais (materiais e simbólicos) colocaram em jogo a hierarquia entre os chefes da aldeia anfitriã e entre as próprias aldeias; no caso do Quarup em planejamento para o homem jagamü falecido, os brancos surgem como único motivo do ritual, provocando incômodo, em conjunto com a ideia de que não se deveria fazer um Quarup para alguém que não era chefe, em uma aldeia que ainda não homenageia seus mortos. Por trás de um ritual que é muitas vezes lido na chave da comemoração de um "sentimento de unidade" (Junqueira \& Vitti 2009:146) da sociedade xinguana há complexas redes de alianças e conflitos subestimadas pelas etnografias.

Estiveram em jogo nesses casos as prerrogativas de pessoas e lugares para ocupar a posição de donos-patrocinadores de rituais. Como argumenta 
Harrison (1992), prerrogativas rituais podem ser vistas como equivalentes a "bens de luxo" em economias materiais. Harrison toma o conceito emprestado de Appadurai, segundo o qual bens de luxo não necessariamente se opõem a bens necessários, mas desempenham uma função retórica e social, como "signos encarnados" de relações sociais (Appadurai 1986:38). Harrison propõe ser possível substituir o termo "bens" por "ações", o que resultaria em uma definição dos atos rituais como "actions that are incarnated signs, actions with the rhetorical function of signifying political relationships" (Harrison 1992:237).

Ao significarem relações políticas, essas formas especiais de ação seriam comparáveis a objetos de luxo em economias de dádivas como o Kula: signos que definem e comunicam a posição de seus possuidores, e cuja posse ou circulação pode ser objeto de competição. Como ele mesmo diz,

O ritual é, por assim dizer, uma modalidade de ação social de luxo ou de "prestígio". Esta é a definição de ritual que vou usar: da mesma forma que bens como os objetos de valor do Kula constituem a esfera do prestígio em uma escala hierarquizada de classes de objetos, o "ritual" constitui a esfera do prestígio em uma escala hierarquizada de classes de ação. Para dizer de forma mais concisa, o ritual está para a ação assim como a retórica está para o discurso, e objetos de luxo estão para bens ordinários (Harrison 1992:238, grifos no original).

Ser dono de um ritual no Alto Xingu não é a mesma coisa que ser seu "proprietário", mas sim um tipo de mediador (De Vienne \& Allard 2005:131). No caso dos rituais para espíritos, o dono do ritual é um mediador entre o espírito e a aldeia; no caso dos rituais regionais, os donos são mediadores entre o grupo local e os estrangeiros. Ainda assim, no caso dos rituais de chefia, a posição de donos se aproxima de uma prerrogativa, pois apenas chefes e seus parentes próximos podem ocupar essa posição, bem como apenas aldeias-esteio idealmente sediariam esse tipo de evento. Mesmo sem se tratar de relações de propriedade, como nos casos analisados por Harrison, a limitação da prerrogativa a uma categoria de pessoas faz com que suas relações com esses rituais comuniquem uma identidade entre os donos e suas festas: são chefes aqueles que patrocinam festas para chefes, e vice-versa.

Como diz Munn (1992 [1986]), a troca de dons provoca uma expansão do espaço-tempo intersubjetivo da pessoa, ou sua "ampliação" (fundamentando, assim, o reconhecimento de pessoas de destaque em sistemas de trocas como "grandes" ou "famosas"). Levando a comparação adiante, Harrison afirma que 
[...] o executante no ritual e na magia — como um jogador no sistema do Kula — simultaneamente projeta e extrai sua identidade de um universo de relações sociais que transcende seu próprio tempo e lugar. A participação neste mundo mais amplo é um privilégio importante, e é a medida da posição ou status de um homem (Harrison 1992:239).

Harrison observa que as expansões em um e outro caso seriam diferentes, pois enquanto a circulação de riquezas materiais inseriria a pessoa em um sistema transétnico de relações sociais, a posse de riquezas imateriais conectaria a pessoa com um universo de relações com o passado mítico. No caso xinguano, ambos os aspectos parecem estar reunidos, pois é a identificação dos donos e dos mortos homenageados no Quarup com os chefes míticos que amplia a inserção dessa categoria de pessoas na rede regional xinguana - inclusive na posição de parceiros na troca de objetos de luxo, um componente central dos rituais regionais.

Assim, ser dono de um Quarup é um índice de chefia, e ser dono de um Quarup para uma autoridade é um índice de grandeza do chefe patrocinador e sua aldeia para além das fronteiras deste complexo regional. Com a ampliação da escala dos rituais e a inclusão dos brancos, questões da política local e regional se tornam mais explícitas, evidenciando como a objetivação dos rituais oferece a chefes e a aldeias a possibilidade de reiterarem ou reverterem relações hierárquicas ligadas à posição de dono.

\section{Domesticando chefes}

Por que, do ponto de vista xinguano, o ritual mortuário da nobreza parece um contexto adequado para construir alianças com não índios, principalmente autoridades? Segundo Marcela Coelho de Souza (comunicação pessoal, 2009), os Kĩsêdjê costumam comparar suas estratégias políticas com as de seus vizinhos do sul, ou seja, com os alto-xinguanos. Os primeiros, em suas reivindicações, preferem usar uma estética guerreira e o enfrentamento verbal pela "fala dura", ideais ligados a um ethos partilhado com outros jê. Não se conformam, contudo, que os alto-xinguanos, quando têm queixas ou reivindicações a fazer, muitas vezes prefiram convidar políticos e funcionários do Estado para festas, ou então homenagear seus parentes mortos. Isto talvez se explique pelo fato de que tais modos de ação política podem não ser simples "estratégias" diferentes, mas transformações de regimes distintos de lidar com a alteridade.

A associação de autoridades não indígenas a chefes no Quarup (como mortos homenageados, convidados de honra, ou donos-patrocinadores) evoca 
situações de outros ameríndios que também parecem optar por colocar os brancos na posição de "chefes" ou "donos" em certos contextos - figuras da maestria e do domínio amplamente distribuídas nas cosmologias ameríndias, que reúnem ao mesmo tempo as capacidades de predar e de cuidar, de agressão e generosidade (Bonilla 2005).

É frequente entre os povos ameríndios a concepção de que tudo e todos tenham um "dono" ou "mestre". Segundo a síntese de Fausto, o conceito de dono "designa uma posição que envolve controle e/ou proteção, engendramento e/ou posse, e que se aplica a relações entre pessoas (humanas e não humanas) e entre pessoas e coisas (tangíveis ou intangíveis)" (Fausto 2008:330). Entre os Kalapalo, praticamente tudo e todos têm um dono, e quando se trata de coletivos (humanos ou não), seus donos também são seus chefes. Este tipo de agente é visto ao mesmo tempo sob a forma de um predador/afim potencial e de um protetor/consanguíneo. As principais insígnias dos chefes humanos são índices de animais predadores, como objetos de couro e garras de onça (chefe de todos os animais terrestres), e penas e pinturas de harpia (um dos mais importantes chefes dos pássaros, ao lado de outras aves de rapina e do Urubu-Rei).

Entre os coletivos de espíritos-animais, seus chefes são seres tidos como agressivos, de tamanho excessivo ou com alguma característica corporal que os marca como diferentes. Assim é o caso do Hiper Veado, chefe dos veados, por sua grande galhada, e do Hiper Peixe-Cachorra, chefe dos peixes, por seus dentes ameaçadores. A condição de afim potencial dos chefes também é marcada pelo respeito (titsangi) que se deve a eles, o que no passado, segundo dizem os Kalapalo, implicava não pronunciar seu nome (como acontece com afins efetivos) e manter distância de sua casa, se ela fosse uma casa especial de chefe (evocando a relação entre genros ou noras com seus sogros e sogras que, no início do casamento, devem manter uma distância corporal; sobre as casas de chefe, ver Guerreiro 2013).

Mesmo evidenciando sua condição de afim/predador, um dono-chefe também é visto como um pai adotivo, que cuida de seus filhos (suas "crianças", como os chefes dizem em discursos rituais), oferecendo alimentos, dando conselhos, educando e fomentando a alegria com o patrocínio de festas. A posição de um povo em relação a seu chefe é equivalente àquela de um animal de estimação em relação a seu dono: ambos são "filhos" de seus captores/predadores.

A relação entre um dono-chefe e seu povo é ao mesmo tempo uma relação entre predador e presa, e entre pai e filhos. Estas não são relações excludentes, mas que se implicam mutuamente: é pela predação que se pode produzir uma relação assimétrica entre donos-chefes e seus protegidos 
(Fausto 2008:335). Uma é condição e meio da outra, pois para ser dono-chefe é preciso ser diferente e perigoso, a fim de controlar outros como se fossem suas presas. Porém, a forma desse controle são a nutrição e a proteção, que convertem uma relação de afinidade potencial na produção de consanguinidade (segundo o modelo da "predação familiarizante" de Fausto [2001]).

O domínio não se exerce exclusivamente pelo dono-chefe sobre o grupo, mas também deste sobre o chefe. A posição de mestre/dono não implica apenas controle, mas também, e talvez principalmente, cuidados. Segundo Fausto,

Da perspectiva de quem é adotado-cativado, estar ou pôr-se na posição de um órfão ou de um xerimbabo pode ser não apenas uma injunção negativa e inescapável, mas também um modo positivo [...] de reclamar atenção e generosidade (Fausto 2008:333).

Figueiredo comenta que os Aweti consideram o bom comportamento do chefe como o resultado do trabalho que têm em prepará-lo (Figueiredo 2010), isto é, o chefe não ocupa sua posição por já dispor das qualidades que se esperam dele, mas por ter sido colocado pelo grupo na posição de chefe é que ele deve aprender essas qualidades. Os Kalapalo também investem coletivamente na "pacificação" de seus chefes. Quando um reconhecido feiticeiro não deixa de atacar magicamente suas vítimas, caso ele venha de família nobre, pode-se fazê-lo chefe para que fique calmo e generoso. Todo ano as roças dos principais chefes são abertas coletivamente, para que eles se sintam inclinados a produzir comida e distribuí-la ao grupo, e os pedidos de rituais feitos aos chefes são vistos como formas de agradá-los e mantê-los residindo na aldeia.

A troca de dons entre o chefe e o grupo, principalmente sob a forma de alimentos (mas não só), é uma via de mão dupla pela qual o primeiro captura e domestica seu povo como presa, ao mesmo tempo em que se coloca à sua mercê, pois o grupo também julga capturar e domesticar seus chefes. Como dizia Lévi-Strauss a respeito da hierarquia entre as metades Bororo, "even in these relations of subordination, the principle of reciprocity is at work; for the subordination itself is reciprocal [...]" (Lévi-Strauss 1944:268).

Disso resulta que colocar-se na posição de presa/filho adotivo perante um dono pode ser uma forma ativa, intencional, de extrair do dono aquilo que mais se espera dele: sua generosidade. Dos chefes tradicionais esperam-se comida e objetos, enquanto dos "caciques brancos" esperam-se dinheiro, mercadorias e apoio em projetos políticos. Longe de ser uma situação peculiar aos Kalapalo e mesmo ao Alto Xingu, trata-se de uma modalidade de ação 
difundida na América indígena. Como diz Bonilla sobre os Paumari (falantes de arauá que habitam as margens do médio rio Purus, estado do Amazonas),

pondo-se sistematicamente na posição de presa/animal de estimação (igitha) ou cliente/empregado (pamoari/honaiabono), os Paumari acabaram dominando, até certo ponto, a relação com o interlocutor, forçando este último a adotar a posição de chefe domesticador, ou pai adotivo, e assim assumir a responsabilidade pelo fornecimento de alimentos e mercadorias e por seu bem-estar geral (Bonilla 2008:141).

Assumir a posição de presa em relação a um predador transforma este último em um dono, um pai adotivo, do qual os Paumari julgam conseguir extrair coisas que desejam ou das quais precisam. O que pode parecer à primeira vista um "controle" dos Paumari por seus donos/patrões, de seu próprio ponto de vista é uma forma ativa de controlá-los, um modo de exercer sua agentividade em uma relação cuja outra e perigosa face é seu próprio controle por outrem.

Incorporar os brancos ao esquema de homenagens do Quarup, aproximando-os dos chefes xinguanos, parece estender a essas pessoas um modo de controlar e pacificar seres com capacidades predatórias, forçando-os a agir de forma generosa em proveito do grupo - especialmente chefes tão ambíguos como os "caciques brancos", de índole muito duvidosa.

\section{Maestria, troca e personificação}

Algumas situações chamam a atenção para o lugar da posição de dono na constituição de grupos de diferentes escalas e suas formas de "representação": como uma rede heterogênea de pessoas pode aparecer como uma pessoa ou grupo capaz de ocupar a posição de detentor de práticas acessadas por não índios sob a forma da "cultura"?

A posição de dono de ritual constitui uma relação assimétrica produzida pela troca de dons. A maior parte do que é distribuído pelo dono é de fato uma redistribuição de alimentos obtidos e processados em outros momentos pelo grupo: o mingau de pequi com o qual o dono do Quarup paga os dançarinos foi processado pelas mulheres do grupo no ano anterior; este trabalho, por sua vez, foi pago com peixe obtido em uma pescaria realizada por todos os homens da aldeia etc.

A reunião de alimentos para os convidados do Quarup segue sempre uma mesma lógica: homens e mulheres cooperam, em seus grupos do- 
mésticos, para reunir alimentos crus; os grupos domésticos ofertam estes alimentos aos coordenadores do ritual (tajope, chefes responsáveis por planejar e organizar as atividades rituais), que os preparam; os tajope, por fim, entregam ao dono do ritual o alimento pronto para ser armazenado e, posteriormente, redistribuído. Em outros termos, a aparição pública de um dono distribuidor de alimentos eclipsa as formas através das quais ele foi produzido $^{16}$ (Strathern 1988). O eclipsamento, isto é, a ocultação parcial de relações de produção de um objeto destinado a uma troca mediada, é de natureza hierárquica, pois engloba outras relações (Gell 1999). Estas, porém, não deixam de ser visíveis, o que se expressa por meio da dívida e da vergonha (ihütisu) que ela gera. ${ }^{17}$

Os Kalapalo dizem que tudo o que se oferece em um ritual provoca vergonha no receptor do dom: o dono se envergonha por dançarem em homenagem a seu parente morto no Quarup, ficando obrigado a retribuir com alimentos; ao fazê-lo, o dono "envergonha" as pessoas, que se veem compelidas a dançar, a cantar e a trabalhar mais. Mas o eclipsamento das relações de produção de alimento faz com que tal circulação de dons nunca seja perfeitamente simétrica, de tal maneira que, no momento do clímax do ritual com os grupos convidados, o chefe-dono apareça como o único doador. ${ }^{18}$

Esse movimento sucessivo de eclipsamentos é que permite ao chefe personificar o grupo perante outros, sejam xinguanos ou brancos. Na cosmopolítica alto-xinguana, a produção de um coletivo, de humanos ou não humanos, passa necessariamente pela agência de um chefe-dono, que atua na sua constituição, tornando-o visível para outros. Os Kalapalo só se relacionam enquanto grupo - seja com outros xinguanos no ritual, seja com os brancos - por meio de chefes que, ao se colocarem na posição daqueles que "cuidam de seu pessoal", estabelecem com ele uma relação assimétrica que faz com que o grupo só exista mediante sua ação e apresentação públicas. Ao menos temporariamente, os chefes/donos encarnam o grupo, são o coletivo personificado.

Lima (2005) identifica uma forma de coletivização semelhante entre os Yudjá (tupi, Médio Xingu), segundo a qual não há uma dicotomia estrita entre pessoa e grupo, tampouco uma ideia reificada de grupo. O que existe é uma forma social que "envolve a ação coletiva em ação pessoal, torna equivalente a ação pessoal e a de um grupo" (Lima 2005:97). Não existe grupo sem uma pessoa que desempenhe o que a autora chama de "função-Eu", a qual se coloca em uma relação assimétrica com seus acompanhantes e aparece como aquela capaz de agir e ser o grupo ao mesmo tempo. A assimetria resultante desse processo seria o efeito da apropriação da posição de sujeito por alguém, que coloca os demais na posição oposta de objeto. É importante 
notar que não se trata de uma relação de representação, mas de um fenômeno de natureza diversa. A ideia de representação supõe que aquilo que é representado exista independentemente de seu representante, enquanto a forma social em jogo entre os Yudjá, os Kalapalo e outros ameríndios faz com que um grupo só exista por meio de um chefe ou dono (cf. também Fausto 2008; Sztutman 2012). Trata-se de uma relação de personificação.

O desempenho dessa "função-Eu" pode dar margem a desentendimentos, o que se pode perceber nos debates sobre a patrimonialização do Quarup. Logo após a criação do Programa Nacional do Patrimônio Imaterial, em 2000, o Instituto do Patrimônio Histórico e Artístico Nacional (Iphan) pretendia fazer do Quarup o primeiro bem cultural registrado no Brasil. Foi encomendado um dossiê sobre o ritual (Coelho de Souza 2001), mas os alto-xinguanos não entraram em acordo acerca de seu possível interesse em transformar o Quarup em patrimônio imaterial brasileiro. Segundo me disse uma liderança kalapalo, à época ele havia entendido que, caso fosse transformado em patrimônio, o Quarup passaria a ser "do Brasil", o que lhe parecia absurdo: o Quarup era dos xinguanos, e não da nação.

A questão vem sendo retomada desde 2012 por meio de uma parceria entre a Fundação Darcy Ribeiro e o Iphan. Como já mencionei, em agosto daquele ano a Fundação organizou com os Yawalapíti um Quarup em homenagem a Darcy Ribeiro, para comemorar os 90 anos de seu nascimento. Para a ocasião, foi pleiteado um grande volume de recursos junto ao Ministério da Cultura e ao Iphan, voltados para a organização do ritual (inclusive para transporte, alojamento e alimentação dos mais de 100 convidados não indígenas), sua documentação audiovisual e a implementação de um sistema de energia solar capaz de atender a toda a aldeia. A documentação do ritual, por sua vez, deveria servir como ponto de partida para um eventual inventário do Quarup, caso fosse pedido seu registro como bem cultural, uma das intenções da Fundação.

O antropólogo teve sua homenagem junto à de um chefe mehináku falecido no ano anterior. Os Yawalapíti, a princípio, não haviam se interessado muito pela ideia (não gostaram de receber uma homenagem como "encomenda"), mas aceitaram em parte para atrair a atenção da grande mídia para questões políticas urgentes. Foram convidados jornalistas de diversos veículos de comunicação, e antes da fase final do ritual foi feita uma reunião para deixar claro o motivo pelo qual haviam sido convidados: não bastava escrever sobre a homenagem a Darcy Ribeiro, era preciso ressaltar as questões políticas que estavam sendo levantadas. Na ocasião, foram colocadas grandes faixas nas casas pedindo mais respeito aos direitos indígenas e protestando contra a Portaria 303 da AGU (que fragiliza o direito 
dos povos indígenas ao usufruto de suas terras), a continuidade das obras da hidrelétrica de Belo Monte, na Volta Grande do Xingu, e a PEC 215 (que propõe transferir a competência de demarcação de terras indígenas para o Congresso Nacional). Rituais, que os brancos apreendem como "cultura" e o que tanto eles quanto os xinguanos podem chamar de "política", são aqui inseparáveis.

A então ministra da Cultura, Ana de Hollanda, havia sido convidada e estava presente. Na tarde que antecedeu a chegada dos povos convidados, os Yawalapíti anunciaram que leriam, em nome de todos os povos do Xingu, uma carta com reivindicações que queriam entregar à ministra para que ela a encaminhasse à presidente da República. Afinal, depois de mais de 60 anos com os brancos tentando gerir suas vidas em nome da "cultura", pareceu-lhes que o Ministério da Cultura poderia representá-los perante o Executivo, o que acabou se revelando um engano. Como foi noticiado pela mídia, a ministra se escondeu em uma casa e disse que não sairia até que o conteúdo da carta fosse revelado. A carta foi lida mesmo assim e, depois disso, o ritual prosseguiu com a chegada dos outros xinguanos. Poucas semanas depois, a ministra foi exonerada do cargo.

À noite, um jovem passou mal e quase desmaiou. Suspeitando que isso pudesse estar relacionado à agência de potências sobrenaturais, o rapaz foi levado para a casa do chefe yawalapíti, onde ficou sendo cuidado e observado. Ele se sentiu tonto enquanto estava ao lado da efígie mortuária de Darcy Ribeiro, e disse ter ouvido o espírito do antropólogo morto falar com ele. O espírito de Darcy lhe disse que estava muito incomodado com o que havia acontecido mais cedo, e que os xinguanos deveriam fazer com que a ministra desse uma coletiva de imprensa se desculpando logo pela manhã, antes de a festa prosseguir. Não é comum que alguém ouça os espíritos dos mortos durante o Quarup, mas é um perigo possível. Isto só acontece caso o corpo da pessoa esteja fragilizado, ou tenha sido vítima de um feitiço. Os anfitriões logo criaram uma teoria: o jovem teria sido alvo de ataques mágicos lançados pelos chefes de outros grupos, que supostamente estariam com ciúmes da autoridade que eles estavam homenageando. Grandeza gera inveja, e esta é um dos principais motores da feitiçaria.

Quando os demais xinguanos souberam que o Quarup yawalapíti seria documentado com a possível finalidade de seu registro junto ao Iphan, houve reações contrárias. O problema para aqueles com quem conversei não era a documentação em si, nem a questão da patrimonialização, mas o papel desempenhado pelos Yawalapíti no processo como "donos do Quarup" (não de um Quarup enquanto evento, mas do Quarup enquanto instituição). O incômodo com a situação levou alguns xinguanos a proibir filmagens, ou a 
reter temporariamente equipamentos de fotógrafos e jornalistas. Segundo algumas pessoas, o objetivo não era atingir a Fundação Darcy Ribeiro, nem os repórteres, mas os anfitrióes da festa. Como me disseram, queriam "dar uma lição neles", "deixá-los com vergonha", porque estavam se comportando como se fossem os "únicos donos" do Quarup, enquanto este é um ritual partilhado por todos os grupos da região de forma heterogênea (pois possuem diferentes repertórios musicais e executam partes do ritual de formas distintas).

Como um grupo anfitrião poderia se apresentar perante os não índios como o único intermediário de um ritual feito por todos? Se alguns eventos podem revelar relações assimétricas entre as aldeias, ou entre chefes e não chefes, ocupar a posição de "dono do Quarup" diante dos brancos pareceu aos olhos de alguns convidados indígenas que era instaurada uma assimetria arbitrária entre os povos xinguanos. Do seu ponto de vista, o grupo anfitrião não poderia ocupar a posição de dono perante o Estado nacional; do ponto de vista dos anfitriões, poderia, mas sabiam que isso seria objeto de ações negativas por parte de outros xinguanos, como indica a suspeita de feitiçaria ligada ao adoecimento do rapaz durante a festa. A questão aqui é uma transformação daquela levantada em 2000: a oposição dos xinguanos à existência de um "dono do Quarup" fixo, seja ele o Estado brasileiro ou um povo específico, que eclipse definitivamente as possibilidades que permitem alçar alguém à posição de dono de ritual, rompendo as relações de reciprocidade nela implicadas.

Segundo Strathern (1992:188), em economias do dom, a distinção entre pessoas e coisas não é dada de antemão - este seria justamente um dos efeitos da troca. Ela argumenta que a dádiva está atrelada a uma forma social na qual os objetos assumem a forma de pessoas, isto é, na qual as coisas são vistas como "partes" de pessoas que precisam ser extraídas delas para se tornarem transacionáveis. Em tais regimes um objeto só se torna transacionável porque pode ser destacado de alguém (:270). Mas este procedimento apenas é possível se o doador tiver um receptor em potencial e for capaz de prever qual será seu ponto de vista sobre ele enquanto doador. Ou seja, a separação entre uma pessoa e algo que ela possa transformar em objeto de troca só ocorre se o doador for capaz de antecipar a reação futura do receptor (um contradom): "O doador só tem objetos à sua disposição porque ele ou ela pode antecipar a perspectiva de extração do receptor" (1992:178).

Deste ponto de vista, o receptor pode ser visto como a causa das ações do doador, e a troca de dons, como um tipo de relação baseada "na capacidade dos atores (agentes, sujeitos) extraírem ou eliciarem de outros itens que então se tornam objeto de sua relação" (:186). Disso resulta que nem os objetos trocados, nem os agentes trocadores existem enquanto tais antes 
da relação de troca: é por meio da dádiva que pessoas constituídas por múltiplas relações destacam algo de si para produzir um efeito sobre outrem e se tornam agentes, o que só são capazes de fazer porque cada um projeta uma imagem de sua contraparte (:178-179).

Os rituais objetivados como "cultura" podem ser vistos como dádivas e como tal atuam na mútua produção dos trocadores como agentes. Os alto-xinguanos eliciam a capacidade dos brancos de oferecer dinheiro, mercadorias e apoio político, e assim o fazem com o intuito de acessar a sua "cultura". Porém, essa "cultura" é ela mesma o resultado de movimentos de coletivização e personificação nos quais a dádiva, seja de alimentos, dinheiro ou mercadorias, viabiliza a produção e a exibição de coletivos como agentes na forma de seus chefes - movimento que supõe o eclipsamento de outras relações, e que por isso se torna foco de tensão.

Um dono que se coloca na posição de sujeito (assume a função-Eu), em contrapartida, coloca outrem na posição de objeto. O "dono do tabaco", ao personificar aquela planta, permite que ela seja feita objeto de sua ação e dos humanos. O "dono dos caramujos", por sua vez, retira partes do seu corpo que, entregues aos Kalapalo, se tornam matéria-prima para a produção de colares. Parece ser esta assimetria que faz com que a posição de dono crie tantas complicações quando algo central para a produção de pessoas e coletivos como o Quarup é transformado em um tipo de "objeto" que se destaca dos alto-xinguanos para mediar suas relações com os brancos. Quando os xinguanos se voltaram contra a posição de um povo específico como mediador de um possível processo de patrimonialização do Quarup, se opuseram à fixação de um dono que, na contrapartida de atuar como sujeito perante os brancos, talvez pudesse colocar os outros grupos na posição de objetos de sua ação. Nos casos dos rituais kalapalo planejados para personalidades discutidos anteriormente, temos uma situação análoga: a possibilidade de se realizarem festas para os brancos em aldeias tidas como periféricas colocaria a aldeia-esteio kalapalo na posição englobada de "acompanhante".

\section{Considerações finais}

Pelo que foi discutido, vemos que não há uma situação na qual os não índios interajam com "o ritual" como se este fosse um objeto passível de ser simplesmente visto ou apreendido sob as formas reificadas da "cultura" ou do patrimônio, mas há uma incorporação dos não índios e de seus recursos aos esquemas internos de organização do ritual, indissociáveis da política alto-xinguana. Não há uma separação entre o ritual e aqueles que suposta- 
mente apenas a ele assistem, pois estes são englobados por sua lógica e pelas máquinas de produção indígenas: produção de beleza e alegria, produção de grandes chefes e coletivos autônomos. Tendo isto em conta, vê-se que não se trata simplesmente de produzir "festas bonitas para o branco ver", isto é, produzir uma objetivação (estética) da socialidade indígena, sem efeitos sobre os índios ou os brancos. Não seria possível imaginar semelhante movimento no mundo ameríndio, onde toda objetificação é, ao mesmo tempo, índice e causa de relações entre sujeitos (Barcelos Neto 2008:34; Lagrou 2007): toda objetificação exibe, de alguma maneira, as relações que a produziram, enquanto cria ou afeta outras relações.

Os rituais regionais da chefia são a forma convencional pela qual os grupos xinguanos se objetivam, se tornam visíveis uns para os outros. É através da ação ritual que coletivos heterogêneos aparecem como um povo, um sujeito ou um agente no plano do sistema regional. Compreende-se melhor, portanto, por que os rituais são chamados a representar a "cultura xinguana" - eles são a forma propriamente xinguana de tornar a socialidade visível para outros. Porém, essa "cultura", a forma com a qual a sociedade xinguana aparece para fora, é o efeito de um procedimento recursivo, é a objetificação de uma objetificação.

Donos de rituais e nobres (categorias que, no caso dos rituais regionais, se sobrepõem) são centrais tanto para os processos de produzir coletivos e sujeitos (isto é, coletivos-sujeitos da perspectiva de outros xinguanos que participam dos rituais), quanto de produzir rituais como "cultura" (algo capaz de ser percebido pelos brancos como um tipo de "objeto" a ser acessado ou mesmo "consumido"). Mais do que a objetificação temporária de uma ideia abstrata de "cultura indígena", os rituais podem aparecer como uma forma de estender aos não índios os modos kalapalo de se relacionarem com a alteridade e, ao mesmo tempo, de produzirem pessoas e coletivos tipicamente xinguanos por meio destas relações - mas não sem provocar transformações.

Vemos que a noção de dono supõe uma relação de troca que pode fazer seus componentes oscilarem entre as posições de sujeito e objeto, algo que está no centro tanto dos processos de personificação exigidos pelos rituais quanto de desentendimentos entre xinguanos e brancos, e dos xinguanos entre si. Espero que esta análise possa apontar para a possibilidade de se desenvolverem, na etnologia amazônica, etnografias sobre as formas ameríndias da dádiva, e de como seu estudo é capaz de ajudar a compreender não só aspectos constitutivos dos chamados "sistemas regionais", mas também de seus modos de articulação com o mundo não indígena. Isso talvez nos ajude a entender melhor a preocupação do jovem matipu com as recentes estratégias econômicas dos mestres do feitiço. 
Antonio Guerreiro é professor no Departamento de Antropologia, Universidade Estadual de Campinas. E-mail: < jrguerreiro@gmail.com>

\section{Notas}

* Agradeço aos pareceristas anônimos pela leitura cuidadosa do artigo e pelas valiosas sugestões.

${ }^{1}$ Utilizo a expressão brancos em itálico porque ela é uma categoria nativa, amplamente usada pelos alto-xinguanos para se referirem aos não índios em geral. Ela é o equivalente da palavra caraíba (de origem tupi-guarani), que possui variantes em todas as línguas xinguanas (como, por exemplo, kagaiha em karib).

${ }^{2}$ Os alto-xinguanos chamam todos os seus rituais de festas, pois eles têm como principal objetivo produzir alegria. Por isso mesmo são chamados de ailene, palavra formada a partir da raiz para "alegria" (ai-luN-ne, alegria-VBLZ-NMLZ).

${ }^{3}$ As palavras em karib seguem a ortografia produzida pela linguista Bruna Franchetto, em parceria com professores indígenas dos povos karib do Alto Xingu (ver, por exemplo, Franchetto 1997).

${ }^{4}$ Kagaiha significa "não indígena" em karib alto-xinguano, e kuẽgü pode significar "outro", "diferente", "distante", "hiperbólico". Todos os seres podem ter uma versão kuẽgü, marcada por uma ou mais dessas qualidades. Seguindo traduções feitas por Franchetto (2012), sugiro traduzir kagaiha kuẽgü como "Hiper Brancos".

\section{${ }^{5}$ Algumas podem ter fases interaldeias.}

${ }^{6}$ Este me parece um ponto importante, mas que não foi muito desenvolvido nas etnografias. Os rituais regionais (à exceção do uluki, a festa de trocas) constroem uma relação de oposição e competição entre pelo menos dois coletivos: um coletivo de anfitriões oposto a um coletivo (ou mais) de convidados (hagito). Contudo, o coletivo dos anfitriões é sempre constituído pelo principal povo anfitrião (o grupo dos patrocinadores da festa) mais, no mínimo, um povo aliado. O ritual xinguano apresenta um exemplo interessante de como uma relação a dois é sempre um caso particular de relação a três (Lévi-Strauss 2008). Para uma discussão sobre a questão, ver Guerreiro (2012: 377-378). 
${ }^{7}$ No Alto Xingu, há uma categoria de pessoas que podem herdar o título de chefe (anetü) ou "chefa" (itankgo). Apenas alguns dentre os que têm ascendência para isto recebem efetivamente este título, mas como os demais também são pensados como pessoas diferenciadas ("pessoas boas/bonitas/verdadeiras"). Utilizo o termo "nobre" para me referir a todos (Barcelos Neto 2003, 2008).

${ }^{8}$ O termo Quarup é a transformação para o português da palavra kamayurá kwaryp, tornada famosa no contexto do contato (ela designa a árvore com a qual são produzidas as efígies dos mortos).

${ }^{9}$ Pelo menos desde a segunda metade do século XIX, os Kĩsêdjê já costumavam participar de alguns rituais regionais, como o jogo de dardos (jawari). Essa participação sempre foi, entretanto, algo intermitente.

${ }^{10}$ A menos que ele já fosse realizado no "período galáctico" da ocupação do Alto Xingu (Heckenberger 2005), quando várias aldeias gravitavam em torno de aldeias maiores e ritualmente mais importantes (ou mesmo de lugares sagrados/centros rituais não habitados, como parece ter sido o caso do sítio kuikuro Heulugihütü - 2005:90-93).

${ }^{11}$ De fato, um modelo de indigenismo bastante particular, que não se tornou modelo para outros povos e regiões.

${ }^{12}$ Aparentemente, ele já havia sido homenageado em um Quarup, o que de início teria provocado alguma resistência e estranhamento.

${ }^{13}$ Processos equivalentes parecem ser recorrentes em economias rituais que passaram por uma rápida intensificação, como nos casos do potlatch norte-americano (Codere 1950), do moka melanésio (A. Strathern 2007 [1971]) e dos rituais xikrin no Brasil (Gordon 2006).

${ }^{14}$ Em 2009, por exemplo, os Kalapalo e os Matipu se envolveram em uma breve querela por causa do local de enterro e realização do Quarup do filho de um chefe kalapalo da década de 1940, que vivia entre os Yawalapíti. Quando os Kalapalo souberam de sua morte, planejaram buscar seu corpo para enterrá-lo em Aiha e fazer um Quarup para ele. Qual não foi sua surpresa quando souberam que os Matipu já haviam ido até os Yawalapíti e reclamado o corpo (pois a avó materna do morto era matipu). Os Kalapalo consideraram o ocorrido uma grande ofensa; já os Matipu, ao procederem dessa forma, tinham a intenção de perpetuar sua linha de chefia em sua própria aldeia, ao proporem a seu único filho homem que patrocinasse um Quarup em memória de seu falecido pai.

${ }^{15}$ As pesquisas arqueológicas de Heckenberger (2005) sugerem que no período de 1250-1700 d.C. encontravam-se no Alto Xingu grandes aldeias e centros rituais em torno dos quais se organizavam, no geral segundo os pontos cardeais, aldeias menores estando ligadas entre si e aos centros por grandes estradas. Esse momento da história xinguana foi chamado de "período galáctico", referência à tendência de hierarquização das relações entre centros político-rituais mais importantes e "grupos satélites". 
${ }^{16}$ Como os donos do Quarup estão de luto, espera-se que eles permaneçam ocultos em suas casas, e só apareçam em público para distribuir alimento aos dançarinos e trabalhadores.

${ }^{17}$ As concepções kalapalo sobre dívidas mereceriam uma descrição mais detalhada, mas que não caberia nos limites deste trabalho. Espero desenvolvê-las em outra ocasião.

${ }^{18}$ Entre os Kalapalo, nos discursos rituais que os coordenadores da festa (tajope) fazem para recepcionar os chefes convidados, o dono do Quarup é chamado de “aquele que tem muita comida" (Guerreiro 2012:335).

\section{Referências bibliográficas}

APPADURAI, Arjun. 1986. "Introduction: commodities and the politics of value". In: (org.), The social life of things. Cambridge: Cambridge University Press. pp. 3-63.

BARCELOS NETO, Aristóteles. 2003. "Festas CARDOSO, Marina Denise; GUERREIRO para um 'nobre': ritual e (re)produção sociopolítica no Alto Xingu". Estudios Latinoamericanos, 23:63-90.

- 2006. "Des villages indigènes aux musées d'anthropologie". Gradhiva, 4:87-95.

_.2008. Apapaatai: rituais de máscaras no

BASTOS, Rafael José Menezes. 1983. "Sistemas políticos de comunicação e articulação social no Alto Xingu". Anuário Antropológico, 81:43-58.

. 1992. "Exegeses Yawalapiti e Kamayura sobre a criação do Parque Indígena do Xingu e a Invenção da Saga dos Irmãos Villas Boas". Revista de Antropologia, 30:391-426.

BONILLA, Oiara. 2005. "O bom patrão e o inimigo voraz: predação e comércio na cosmologia paumari". Mana. Estudos de Antropologia Social, 11(1):41-66.

. 2008. "The skin of history: paumari perspectives on conversion and transformation". In: A. Vilaça \& R. Wright (orgs.), Natives christians: modes and effects of christianity among Indigenous Peoples of the Americas. Farnham and Burlington: Ashgate Publishing. pp. 127-146. JÚNIOR, Antonio Roberto \& NOVO, Marina Pereira. 2013. "As flechas de Maria: xamanismo, poder político e feitiçaria no Alto Xingu". Tellus, 23:11-33.

CARNEIRO DA CUNHA, Manuela. 2009. "'Cultura' e cultura: conhecimentos tradicionais e direitos intelectuais". In: Cultura com aspas. São Paulo: Cosac \& Naify. pp. 311-387.

CARVALHO, Jailton. 2004. "Bastos promete demarcar terras indígenas até 2006". O Globo, p. 2, 15/08/2004.

CLASTRES, Pierre. 2003. A sociedade contra o Estado. São Paulo: Cosac \& Naify. . 2004. "A economia primitiva". In: Arqueologia da violência. Pesquisas de antropologia política. São Paulo: Cosac \& Naify. pp. 173-195.

COELHO DE SOUZA, Marcela Stockler. 2001. "Quarup: a festa dos mortos no Alto Xingu". Dossiê para eventual registro de bem cultural imaterial. Mimeo. 
- 2009. "Objetivação da cultura e regimes de subjetivação: perspectivas etnográficas". Brasília. Projeto de pesquisa. 36 pp. Mimeo.

_. 2010. "A cultura invisível: conhecimento indígena e patrimônio imaterial". Anuário Antropológico, 2009/I: 149-174.

CODERE, Helen. 1950. Fighting with property. A study of Kwakiutl potlatching and warfare, 1792-1930. New York: J. J. Augustin.

DELEUZE, Gilles \& GUATTARI, Félix. 2002. Mil platôs. Capitalismo e esquizofrenia. vol. 5. São Paulo: Editora 34. DESCOLA, Philippe. 2001. "The genres of gender: local models and global paradigms in the comparison of Amazonia and Melanesia". In: T. Gregor \& D. Tuzin (orgs.), Gender in Amazonia and Melanesia: an exploration of the comparative method. Berkeley: University of California Press. pp. 91-114.

DE VIENNE, Emmanuel \& ALLARD, Olivier. 2005. "Pour une poignée de dollars? Transmission e patrimonialisation de la culture chez les Trumai du Brésil central". Cahiers des Amériques Latines, 48-49:126-165.

FAUSTO, Carlos. 2001. Inimigos fiéis: história, guerra e xamanismo na Amazônia. São Paulo: Edusp.

. 2007. "Entre o passado e o presente: mil anos de história indígena no Alto Xingu". Revista de Estudos e Pesquisas, 2:9-52.

- 2008. "Donos demais: maestria e domínio na Amazônia". Mana. Estudos de Antropologia Social, 14(2): 329-366.

FERREIRA, Jorge. 1957. "Kuarup". O Cruzeiro, 15:58-71.

FIGUEIREDO, Marina Vanzolini. 2010. A flecha do ciúme. O parentesco e seu avesso segundo os Aweti do Alto Xingu. Tese de Doutorado, PPGAS-Museu Nacional/UFRJ.
FIORINI, Marcelo \& BALL, Christopher. 2006. "Le commerce de la culture, la médecine rituelle et le Coca-Cola". Gradhiva, 4:97-113.

FRANCHETTO, Bruna. 1997. Tisakisü. Livro da escrita para os povos karib da Terra Indígena do Xingu. Brasília: ISA/MEC. . 2011. "Evidências linguísticas para o entendimento de uma sociedade multilíngue: o Alto Xingu". In: B. Franchetto (org.), Alto Xingu: uma sociedade multilíngue. Rio de Janeiro: Museu do Índio - Funai. pp. 3-38.

_ 2012. "Línguas ameríndias: modos e caminhos da tradução". Cadernos de Tradução, 2(30):35-62.

FRANCO NETO, João Veridiano. 2010. Xamanismo kalapalo e assistência médica no Alto Xingu: estudo etnográfico das práticas curativas. Dissertação de Mestrado, Departamento de Antropologia, Unicamp.

FUNAI. 2004. "Índios do Xingu fazem Kuarup para Dr. Roberto Marinho". Brasília. Disponível em: <http://www. funai.gov.br/ultimas/noticias/2_semestre_2004/ Agosto/ un0617_001.htm>. Acesso em: 16/06/2010.

GELL, Alfred. 1999. "Strathernograms, or, the semiotics of mixed metaphors". In: ___. (org.), The art of anthropology: essays and diagrams. London \& New Brunswick, NJ: The Athlone Press. pp. 29-75.

GORDON, César. 2006. Economia selvagem: ritual e mercadoria entre os Xikrin-Mebêngôkre. São Paulo e Rio de Janeiro: Editora da Unesp/ ISA/NuTI.

GREGOR, Thomas. 1990. "Uneasy peace: intertribal relations in Brazil's Upper Xingu". In: J. Haas (org.), The anthropology of war. Cambridge: Cambridge University Press. pp. 105-124. GREGORY, C. A. 1982. Gifts and commodities. London \& New York: Academic Press. 
GUERREIRO, Antonio. 2011. "Refazendo corpos para os mortos: as efígies mortuárias kalapalo". Tipití: Journal of the Society for the Anthropology of Lowland South America, 9(1):1-29. 2012. Ancestrais e suas sombras: uma etnografia da chefia kalapalo e seu ritual mortuário. Tese de Doutorado, Departamento de Antropologia, Universidade de Brasília.

- 2013. "A chefia xinguana e suas Casas". Temáticas, Dossiê Casas, 42:75-113.

HARRISON, Simon. 1992. "Ritual as intellectual property". Man, 27(2):224-244. . 1993. "The commerce of cultures in Melanesia". Man, 28(1):139-158.

HECKENBERGER, Michael J. 2005. The ecology of power: culture, place, and personhood in the Southern Amazon, A.D. 1000-2000. New York: Routledge. . et al. 2003. "Amazonia 1492: Pristine Forest or cultural parkland?". Science, 301(5640):1710-1714.

2008. "Pre-Columbian urbanism, anthropogenic landscapes, and the future of the Amazon". Science, 321(5893):1214-1217.

HUGH-JONES, Stephen. 2013. "Bride-service and the absent gift". Journal of the Royal Anthropological Institute, 19(2):356-377.

IRELAND, Emilienne Marie. 1993. "Witchcraft accusations and political succession in a Xingu society". Lowland South America Indians Conference. Bennington: Bennington College. Mimeo.

JUNQUEIRA, Carmen \& VITTI, Vanessa Taciana. 2009. "O Kwaryp kamaiurá na aldeia de Ipavu". Estudos Avançados, 23(65):133-148.

KELLY, José Antonio. 2001. "Fractalidade e troca de perspectivas". Mana. Estudos de Antropologia Social, 7(2):95-132.

LAGROU, Els. 2007. A fluidez da forma: arte, alteridade e agência em uma sociedade amazônica. Rio de Janeiro: Toobooks Editora.
LÉVI-STRAUSS, Claude. 1944. "Reciprocity and hierarchy". American Anthropologist, New Series, 46(2):266-268. . 2008. "As organizações dualistas existem?". In: Antropologia estrutural. São Paulo: Cosac \& Naify. pp. 147-178.

LIMA, Tânia Stolze. 2005. Um peixe olhou para mim: o povo Yudjá e a perspectiva. São Paulo e Rio de Janeiro: ISA/ Editora Unesp/NuTI.

MUNN, Nancy. 1992 [1986]. The fame of Gawa. A symbolic study of value transformation in a Massim (Papua New Guinea) society. Durham and London: Duke University Press.

STENGERS, Isabelle. 2010. Cosmopolitics. Minneapolis: University of Minnesota Press.

STRATHERN, Andrew. 2007 [1971]. The rope of Moka. Big-men and ceremonial exchange in Mount Hagen New Guinea. Cambridge: Cambridge University Press.

. 1988. The gender of the gift: problems with women and problems with society in Melanesia. Berkeley: University of California Press.

. 1992. "Qualified value: the perspective of gift exchange". In: C. Humphrey \& S. Hugh-Jones (orgs.), Barter, exchange and value. An anthropological approach. Cambridge: Cambridge University Press. pp. 169-191.

SZTUTMAN, Renato. 2012. O profeta e o principal: a ação política ameríndia e seus personagens. São Paulo: Edusp.

VIVEIROS DE CASTRO, Eduardo. 2002. "Perspectivismo e multinaturalismo na América indígena". In: __. (org.), A inconstância da alma selvagem. São Paulo: Cosac \& Naify. pp. 345-399.

VON DEN STEINEN, Karl. 1940. Entre os aborígenes do Brasil Central. São Paulo: Departamento de Cultura. - 1942. O Brasil Central: expedição em 1884 para a exploração do rio Xingu. São Paulo: Companhia Editora Nacional. 


\section{Resumo}

O famoso Quarup - um grande ritual mortuário realizado pelos povos do Alto Xingu em honra a chefes falecidos - tem sido cada vez mais visto pelos xinguanos como uma ocasião apropriada para receber visitantes brancos, a fim de obter recursos materiais, criar alianças políticas e chamar a atenção da mídia para assuntos indígenas. A partir da descrição de alguns rituais mortuários organizados nos últimos anos, este artigo discute como a objetificação dos rituais como "cultura" para os não índios põe em movimento processos políticos de escala local, regional e nacional. A intenção é compreender como os rituais se tornaram uma dobradiça entre o mundo dos brancos e a política ritual indígena, e como isso pode afetar as formas xinguanas de produzir pessoas e coletivos. Além disso, espera-se esclarecer alguns aspectos das ideias xinguanas sobre a chefia e a noção de "dono".

Palavras-chave Etnologia indígena, Política ameríndia, Ritual, Dádiva, Alto Xingu.

\section{Abstract}

The famous Quarup - a great mortuary ritual carried out by the peoples of the Upper Xingu in honour of deceased chiefs has been increasingly seen by Xinguanos as an appropriate occasion to welcome white visitors, in order to obtain material resources, create political alliances, and call the media's attention to indigenous issues. Based on the description of some of the mortuary rituals held in the last few years, this paper discusses how the objectification of rituals as "culture" to nonIndians puts in motion political processes at local, regional and national scales. The article intends to understand how rituals have become a hinge between the white world and indigenous ritual politics, and how this may affect Xinguano forms of producing persons and collectives. Finally, I expect to clarify some aspects of Xinguano ideas on chieftaincy and the concept of "owner".

Key words Ethnology, Amerindian politics, Ritual, Gift, Upper Xingu. 